\title{
Direct Taxes Code (DTC): What Does it Seek to Achieve?
}

\author{
Vaneeta Rani*
}

\begin{abstract}
DTC seeks to consolidate and amend the law relating to all direct taxes, namely income tax, dividend distribution tax and wealth tax so as to establish an economically efficient, effective and equitable direct tax system which will facilitate voluntary compliance and help increase the tax-GDP ratio. All the direct taxes have been brought under a single code and compliance procedures unified, which will eventually pave the way for a single unified taxpayer reporting system. The need for DTC arose from concerns about the complex structure of half a century old Income Tax Act, 1961, which has been amended a large number of times, making it incomprehensible to the average taxpayer.
\end{abstract}

Keywords: Direct Taxes Code, Tax-GDP ratio, Tax base.

\subsection{Need for DTC}

In the Central Government Budget for 2009-10, the importance of continuing the process of structural changes in direct taxes was reiterated and a comprehensive code to this effect was envisaged. The Government signalled its intention to consolidate and comprehensively amend the existing Income Tax Act 1961 and Wealth Tax Act 1957 through a single legislation, by releasing a draft Direct Taxes Code (DTC) and a Discussion Paper for public comments in August 2009. Based on analysis of the numerous inputs received from stakeholders, a Revised Discussion Paper was released in June 2010 followed by the introduction of the Direct Taxes Code Bill, 2010 in Parliament in August 2010. It was proposed to make it effective from April 1, 2012.

However, the Union Finance Minister informed the Parliament in his budget speech for 2012-13 that the Government received the Report of the Parliamentary Standing Committee on March 9, 2012. Enactment of DTC would take place after the report is examined.

* Associate Professor, Government Bikram College of Commerce, Patiala, Punjab. 
In his Budget Speech for 2013-14, the Finance Minister observed, "The Direct Taxes Code (DTC) work is in progress. The DTC is not intended to be an amended version of the Income-tax Act, 1961 but a new code based on the best international practices that will be compatible with the needs of a fast developing economy. The Standing Committee on Finance has submitted its report and we attach great weight to its recommendations. My team in the Ministry of Finance is examining the recommendations and I intend to work with the Standing Committee and its Chairman in order to finalise the official amendments. I shall endeavour to bring the Bill back to this House before the end of the Budget Session."1

\section{Objectives and Salient Features of DTC}

\subsection{Objectives}

As the marginal tax rates have been steadily lowered and the rate structure rationalised to reflect best international practices, any further rationalisation of the tax rates may not be feasible without corresponding increase in the tax base to enhance revenue productivity of the tax system and improve its horizontal equity. Hence, a three-fold strategy for broadening the base has been articulated in the DTC.

The first element of the strategy is to minimise exemptions that have eroded the tax base. The removal of these exemptions would (a) increase tax-GDP ratio, (b) enhance GDP growth, (c) improve equity (both horizontal and vertical), (d) reduce compliance costs, (e) lower administrative burdens and (f) discourage corruption.

The second element of the strategy seeks to address the problem of ambiguity in the law which facilitates tax avoidance.

The third element of the strategy relates to checking of erosion of the tax base through tax evasion.

\subsection{Salient Features}

The salient features of DTC are as under:

1. It consolidates and integrates all direct tax laws and replaces both the Income Tax Act 1961 and the Wealth Tax Act 1957 with a single legislation.

2. It simplifies the language of the legislation. The use of direct, active speech, expressing only a single point through one sub-section and rearranging the provisions into a rational structure will assist a layperson to understand the provisions of the DTC.

3. It indicates stability in direct tax rates. Currently, the rates of tax for a particular year are stipulated in the Finance Act for that relevant year. Therefore, even if there is no change proposed in the rates of tax, the Finance Bill has still to be passed indicating 
the same rates of tax. Under DTC, all rates of taxes are proposed to be prescribed in Schedules to DTC, thereby obviating the need for an annual Finance Bill, if no change in the tax rate is proposed. DTC proposes a corporate tax rate of 30 percent against the current effective rate of 33.2 percent and raises the exemption limit as well as broadens the tax slabs for personal income tax.

4. It strengthens taxation provisions for international transactions. In the context of a globalised economy, it has become necessary to provide a stable framework for taxation of international transactions and global capital. This has been reflected in the new provisions. The new provisions with regard to international taxation are the following:

- Advance Pricing Agreements for International Transactions: This will bring in certainty in transfer-pricing issues as any taxpayer can enter into an agreement with the tax administration, which will be valid for a period up to five years, regarding the manner in which the taxpayer would compute arm's length price in respect of the taxpayer's international transactions.

- Alignment of concept of residence (of a Company) with India's tax treaties by introduction of concept of place of effective management instead of wholly controlled in India.

- Controlled Foreign Company Regulations: This is a provision which will assist in taxation of profits of a foreign company in the hands of resident share- holders who may have incorporated such a company in low tax jurisdictions and are accumulating passive income (i.e. interest, dividends, capital gains etc.) in the company without repatriating the income to India.

- Branch Profit Tax on Foreign Companies: Currently, foreign companies are taxed at the rate of 42.2 percent (inclusive of surcharge and cess) while domestic companies are taxed at the rate of 33.2 percent (inclusive of surcharge and cess) plus a dividend distribution tax at the rate of 16.6 percent when they distribute dividend from accumulated profits. It is proposed to equate the tax rate of foreign companies with that of domestic companies by prescribing the rate at 30 percent and levying a branch profit tax (in lieu of dividend distribution tax) at the rate of 15 percent. This will provide tax neutrality between a branch and a subsidiary of a foreign company in India.

- Taxation of Assets Held Abroad under Wealth Tax: It is proposed to include certain assets of residents which are held abroad, such as deposits in bank accounts in the case of individuals and interest in a foreign trust or in a controlled foreign corporation. This will create a reporting requirement mechanism for assets held 
abroad.

5. Phasing out profit-linked tax incentives and replacing them by investment-linked incentives: It has been observed that profit-linked deductions are inherently discriminatory, prone to misuse by shifting of profits from non-exempt to exempt entity or by reporting higher profits in exempt income entity, and also lead to high level of litigation and revenue foregone. They also impede the Government's efforts to give a moderate tax rate to other taxpayers as the higher taxes paid by others by implication cross-subsidise the lower tax rates of the profit-linked deduction sectors. Such profit-linked deductions are being phased out of the Income Tax Act and have also been dropped in the DTC. They are being replaced by investment-linked deductions for specified sectors. Investment-linked incentives are calibrated to the levels of creation of productive capacity and therefore are superior instruments. Profit-linked deductions currently being availed of have been protected for the unexpired period in the DTC.

6. Rationalisation of Tax Incentives for Savings: In order to focus savings incentives on long-term savings for social security of the taxpayer during his non-working life, deduction of up to ` 1 lakh has been provided for investments in approved provident funds, superannuation funds, and pension funds.

7. DTC proposes to rationalise the tax incentives for savings through the introduction of the Exempt-Exempt-Taxation (EET) method of taxation of savings. Under this method, the contributions are exempt from tax (this represents the first $E$ under the EET method), the accumulations/accretions are exempt (free from any tax incidence) till such time as they remain invested (this represents the second E) and all withdrawals at any time would be subject to tax at the applicable personal marginal rate of tax (this represents the $\mathrm{T}$ under the EET method).

8. General Anti-avoidance Rule to Curb Aggressive Tax Planning: Direct tax rates have been moderated over the last decade and are in line with international norms. A general anti-avoidance rule assists the tax administration in deterring aggressive tax avoidance in a globalised economy. Such general anti-avoidance rules already form a part of the tax legislation in a number of G-20 countries.

9. Taxation of Non-profit Organisations: It is proposed to tax non-profit organisations set up for charitable purposes on their surplus (at the rate of 15 percent), after allowing for accumulation of a specified proportion for creation of assets or for longterm projects, a further carry forward for receipts of the last month of the year, and also after a basic exemption limit of Rs. 1 lakh. Donations to these non-profit organizations will be eligible for tax deduction in the hands of the donor.

10. DTC argues against area-based exemptions which allocate/divert resources to areas 
where there is no comparative advantage. Such exemptions also lead to tax evasion and avoidance. It proposes that area-based exemptions that are available under the Income Tax Act, 1961 will be grandfathered.

11. Under DTC, residence-based taxation is applied to residents and source-based to non-residents. A resident of India will be liable to tax in India on his worldwide income. However, a non-resident will be liable to tax in India only in respect of accruals and receipts in India (including deemed accruals and receipts).

12. The draft Code simplifies the dualistic concepts of previous year and assessment year used in the Act and replaces them with the unified concept of financial year and decrees that all rights and obligations of the taxpayer and the tax administration will be made with reference to the financial year.

13. DTC also seeks to eliminate the present distinction between short-term investment asset and long-term investment asset on the basis of the length of holding period of the asset. ${ }^{2}$

\section{Endnotes}

1. Government of India, Ministry of Finance, Budget Speech of the Finance Minister, 20132014, Para 154.

2. It may be noted that the Discussion Paper released by the Government argued for special treatment of capital gains under an income tax regime for two reasons. Firstly, taxing gains each year, as they accrue, would strain the finances of an individual who is yet to receive these gains in hand. Secondly, the capital gain realized when a capital asset is sold is usually the accumulated appreciation in the value of the asset over a number of years. The bunching of such appreciation in the year in which the asset is sold pushes the seller into a higher marginal tax bracket, if the value of the asset is sufficiently high. As such, if no special treatment is accorded to capital gains, a progressive income tax would discriminate against those whose income from capital assets is in the form of capital gains as compared to those whose income is derived from interest or dividends. 